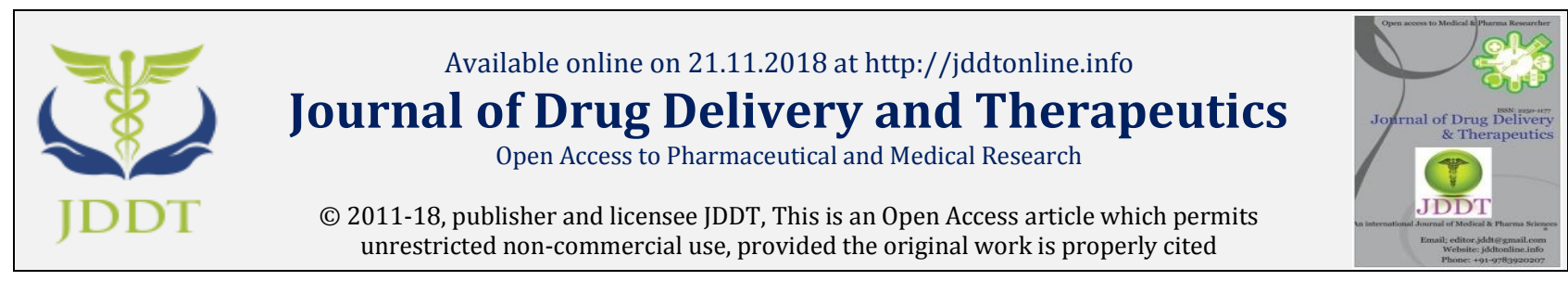

Open $\odot$ Access

Review Article

\title{
Ayurveda description of Panchkarma for the management of life style disorders
}

\author{
${ }^{1 *}$ Dr. Rishi Mishra, ${ }^{2}$ Dr. Sanjeev Khuje, ${ }^{3}$ Dr. Jinesh Jain, ${ }^{4}$ Dr. O. P. Dwivedi \\ ${ }^{1}$ M.D. Ph.D. (Sch.), Reader, Rajiv Gandhi Ayurved College, Bhopal, India. \\ ${ }^{2}$ M.D. Ph.D, HOD, Dept. of Rognidan, Govt. Ayurveda College, Rewa, India. \\ ${ }^{3}$ M.D. Ph.D., HOD, Dept of Panchakarma, Govt. Ayurveda College, Rewa, India. \\ ${ }^{4}$ M.D. Ph.D., Professor, HOD, Dept. of Rachna Sharir, Govt. Ayurveda College, Rewa, India.
}

\begin{abstract}
Ayurveda is indigenous system of medical science offers various therapeutic modalities for the management of healthy living. Ayurveda not only emphasized curative approaches for health management but also suggested some preventive measures as. Panchakarma is one of them which come under Shodhana Chikitsa of ayurveda system; it play crucial role towards the prevention and treatment of various diseases. Panchakarma offers calming and detoxifying effect, it improves circulation, balances mood \& behavior, regulate metabolic activities and boost muscular tone therefore recommended for various diseases related to the disturbed pattern of life style such as; obesity, thyroid, diabetes, sleeplessness, headache, depression and anxiety. Different approaches of Panchakarma therapy like; Vamana, Virechana, Basti, Nasya, Raktamokshana, Shirodhara and Abhyanga may be utilized effectively for the management of above mentioned life style disorders. Present article summarized therapeutic importance of Panchakarma therapies for the management of diseases which occurs due to the in disciplinary life style pattern.
\end{abstract}

Keywords: Ayurveda, Panchakarma, Diabetes, Depression and Anxiety.

Article Info: Received 05 Oct, 2018; Review Completed 06 Nov 2018; Accepted 14 Nov 2018; Available online 21 Nov 2018

\section{Cite this article as:}

Mishra R, Khuje S, Jain J, Dwivedi OP, Ayurveda description of Panchkarma for the management of life style disorders, Journal of Drug Delivery and Therapeutics. 2018; 8(6):397-399 DOI: http://dx.doi.org/10.22270/jddt.v8i6.2062

*Address for Correspondence:

Dr. Rishi Mishra, M.D. Ph.D. (Sch.), Reader, Rajiv Gandhi Ayurved College, Bhopal, India.

\section{INTRODUCTION}

Life style related disorders are rapidly growing medical problem in India due to the disturbed and stressed living of mass population. Avoidance of early wake up, lack of exercise, disturbed timing of meal and sleep, bad food habits and ignorance of principles of sadavrita induced pathogenesis of various diseases such as; thyroid, obesity, diabetes, sleeplessness, migraine, depression, cardio vascular elements, high cholesterol, hypertension, stroke and anxiety ${ }^{1-5}$. As per general principle of science these all diseases attributed to the consequences of in disciplinary life style. It is believed that large number of world population currently suffering from such types of diseases due to the increase level of in disciplinary life pattern. Lack of physical exercise, consumption of unhealthy food, late night working culture, day time sleeping habits, chintan, continuous seating on chair, excessive bike riding and exposure to environmental pollution are some major activities associated with modern life style which greatly affecting health of people globally ${ }^{2-6}$. These factors may initiates pathogenesis of symptoms such as; mansavaha dushti, agni dushti, kapha dushti and medovaha dushti which further resulted various chronic disorders. Ayurveda suggested following rules of dincharya as mentioned in ancient text along with preventive approaches such as; Panchakarma. The various modalities of Panchakarma help to balances Doshas, Dhatus, Meda and Mansadushti, Panchakarma also help to remove ama (toxins) therefore prevent lifestyle disorders (figure 1). Panchakarma improves digestion and metabolic processes, boost Agni (table 1) therefore offer significant relief in life style disease such as diabetes ${ }^{7-10}$. 


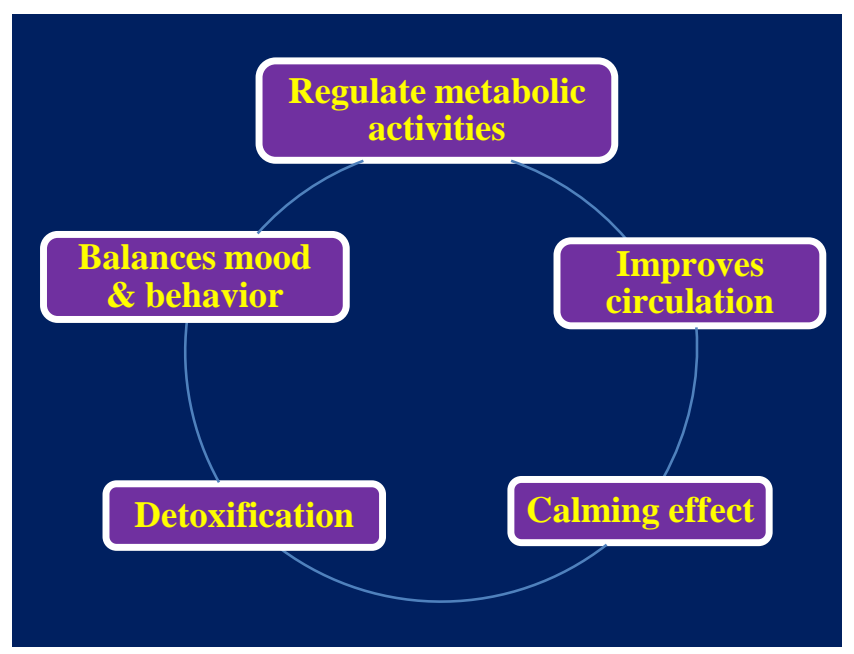

Figure 1: Beneficial effects of Panchakarma in life style disorders

Table 1: Life style related disorders and their management by Panchakarma:

\begin{tabular}{|ll|}
\hline Diseases & Panchakarma \\
\hline Obesity and thyroid & Vamana \\
\hline Hyperacidity, Indigestion & Virechana \\
\hline Back pain, joint pain and spondylitis etc. & Basti \\
\hline Headache, sinusitis, frozen shoulder and sleeplessness & Nasya \\
\hline Sleeplessness, migraine and psychological stress & Shirodhara \\
\hline \hline Body pain, muscle spasm, rigid muscular movement and pain on movement. & Abhyanga \\
\hline
\end{tabular}

\section{Panchakarma for Chittavasada}

Chittavasada (depression) is a psychiatric disorder and stressful life style and sleeplessness considered responsible for Chittavasada along with other factors. Ayurveda described shodhana therapy such as; Panchacarma for the management of Chittavasada due to its calming effect. Approaches of Panchacarma such as; Antarparimarjana offer internal purification, Samshodhana pacifies vitiated Doshas while Bahiraparimarjana provides external purification in Mansa Vikara, therefore Panchacarma therapy relief symptoms of depression. Panchacarma therapy relaxing body, offer calming effect on mind, help in detoxification of accumulated toxins, improve circulation for brain supply, boost nerve functioning and regulate coordination paring of mortar activity, thus relief in neural symptoms of depression.

\section{Panchakarma for Anidra}

Aahara, Nidra and Brahmacharya are the major sub-pillars of life, Nidra is considered vital factor for maintaining normal health status. Anidra (Insomnia) is pathological condition involving loss of sleep due to the bad effect of modern day life and stress. Anidra pathologically involve aggravation of Vata \& Pitta, Vruddhi in Rajasik Guna along with Shleshma and Tama Kshaya. Panchkarma therapy pacifies aggravated Vata \& Pitta, offers calming and shooting effect therefore recommended for the management of Anidra. It is believed that Tila Taila Sarvang Snehan, Sarvang Swedan with Dashmula Kwath and Shirodhara with Tila Taila provide great relief in Anidra. Blockage in respiratory passage \& accumulation of Kappha may sometime disturb sleep, Panchkarma improve respiratory passage \& clear accumulated Kappha, relax mind and impart lightness in whole body therefore promotes sleep.

\section{Panchakarma for Madhumeha}

Madhumeha (diabetes) is also one of the common disorders associated with disturbed conduction of daily routine. It may be present in two broad forms Sthula pramehi and Krusha pramehi. Metabolic derangement and unhealthy lifestyle along with bad food habits initiates pathogenesis of diabetes. Literature study confirm efficacy of Panchakarma in Madhumeha. Various principles of Panchakarma therapy offers different therapeutic benefits in Madhumeha such as; improvement in digestion and Agni to control metabolic processes in body. Various studies suggested that use of Vamana with Madanaphaladi Yoga, Virechana with kalyanaka guda and Snehapana with Dhanwantharam ghrita offers satisfactory result in Madhumeha.

\section{In diabetes Panchakarma therapy offers following beneficial effects:}

$>$ Clarify shrotas

$>$ Reduces peripheral resistance \& prevent deposition of meda

$>$ Liquefy stagnated dosha \& dushya accumulated in micro circulation

> Offers Rakta sodhaka \& Tridosa samaka effect

$>$ Help in the utilization of glucose by peripheral tissue

> Bahu abaddha Meda vilayana \& kapha nasa effect

$>$ Improve circulation and thus metabolic regulation

$>$ Boost Agni, detoxify body and reduces stress one of the etiological factor of diabetes. 


\section{Panchakarma for Tamaka-Shwasa}

Tamaka-Shwasa is pranavaha srotas Vyadhi and after initial predisposition disease may become worsen due to the excessive exposure to environmental pollution as a part of current life style pattern. Hridaya and mahasrotas \& uraha pradesha are sthana of pranavaha srotas which may affected by vitiated Kapha Dosha. Avalambaka, bhodaka and kledhak kapha are mainly responsible for TamakaShwasa. Tamaka-Shwasa clinically involve vitiation of Vata dosha along with Kapha resulting Dushitha Prana Vyau leading to chronic manifestation such as; Hikka, Dushitha \& Swasa. Panchakarma helps in pranavaha srotastha vyadhi pacifying Dosha and eliminating accumulated Dushitha Vayu. Panchakarma detoxify ama and enhance efficiency of Shrotas, clean respiratory passage and boost immune response against allergens. Panchakarma also improve circulation, regularizes heart rhythm and enhances lungs

\section{REFERENCES}

1. Dr. S.G. Huparikar, Dr. V.P. Jogalekar, Textbook of Agadtantra, Ist Edition, Rashtriya Shikshan Mandal Pune, Lecture, 2008, $7: 35$.

2. Susruta Samhita Sutra (26/10), Ayurved Tattva Sandipika Hindi Commentary by Ambika Datta Shastri (2001), 12th edi, Chaukhambha Sansakrit Sansthan Varanasi.

3. Gautam J. Bhaisare, Hemraj Meena, C. R. Yadav, Depression and its Ayurvedic Management, International Journal of Ayurvedic \& Herbal Medicine, 2012; 2(4): 602-606.

4. Astanga Hridaya with the commentaries, Sarvangasundara of Arundutta and Ayurveda rasayana of Hemadri; Uttarsthana 23/24-26; Reprint edition, V.S. 2066 Published by Choukhambha Samskrit series, Varanasi.

5. Chakradatta; Kshudraroga Chikitsa; $3^{\text {rd }}$ edition, 1997, By Dr. Indradeva Tripathi, Chaukhamba Samskrit Sansthan Varanasi. capacity therefore recommended for symptomatic relief in Tamaka-Shwasa.

\section{CONCLUSION}

Ayurveda considered prevention of disease as prime approach than treatment and advised Panchakarma as prophylactic care for many disorders. Shodhana Chikitsa such as Panchakarma offers many beneficial effects in different pathological condition especially associated with disturbed pattern of daily regimen. Panchakarma helps to manage diseases such as; obesity, thyroid, hypertension, headache, sleeplessness, migraine and psychological stress. These all diseases related to the modern day life therefore it can be said that Panchakarma utilized as precautionary and curative approach for the management of diseases which may occurs due to the conduction of in disciplinary life style pattern.

6. Bhaisajya Ratnavali; 73/28-29; Edition 2012, By Kavi Raj Ambica Dutt Shastri, Chaukhamba Sanskrit Sansthana Varanasi.

7. Kashinath Shastri, Gangasahay Pandeya (editor). Charaka Samhita of Charaka, Nidana Sthana, Chapter 4, Verse no. 39, Vol I, 5th edition, Varanasi; Chaukambha Sanskrit Sansthan 1997; 509.

8. Yadavji Trikamji Acharya (editor). Sushruta samhita of Sushruta, Nidana Sthana, Chapter 6, Verse no. 25, 6th edition, Varanasi; Chaukambha Orientalia; 1997; 294.

9. Satyapal Singh, an Appraisal of Bio-Purificatory and Therapeutic Potential of Panchakarma, IJPRS, 2015; 4: I-3.

10. https://www.lybrate.com/topic/how-ayurveda-is-useful-inpreventing-lifestyle, Accessed Oct 2018. 